\title{
In Vitro Evaluation of Ozone Activity on Recent Clinically Isolated Bacterial Strains
}

\author{
P. Tordiglione $^{1 *}$, F. S. M. Araimo Morselli ${ }^{1}$, I. Scarpa ${ }^{1}$, G. Puggioni ${ }^{2}$, C. Mancini ${ }^{2}$, \\ G. Rosa', A. Giordano \\ ${ }^{1}$ Department of Anaesthesiology and Critical Care Medicine, Sapienza University of Rome, Rome, Italy \\ ${ }^{2}$ Department of Public Health and Microbiology, Sapienza University of Rome, Rome, Italy \\ Email: *p.tordiglione@policlinicoumberto1.it
}

Received November 22, 2013; revised December 22, 2013; accepted December 29, 2013

Copyright (c) 2014 P. Tordiglione et al. This is an open access article distributed under the Creative Commons Attribution License, which permits unrestricted use, distribution, and reproduction in any medium, provided the original work is properly cited. In accordance of the Creative Commons Attribution License all Copyrights (c) 2014 are reserved for SCIRP and the owner of the intellectual property P. Tordiglione et al. All Copyright (c) 2014 are guarded by law and by SCIRP as a guardian.

\section{ABSTRACT}

This study aims to evaluate the cozone bactericidal activity in different suspension media (saline, broth and whole blood) at different exposure times. Methicillin-resistant Staphylococcus aureus, Enterococcus faecalis, ESBL- positive Escherichia coli, MDR Pseudomonas aeruginosa were suspended in different media. We used a bacterial concentration of $0.2 \mathrm{MF}$ for all experiments, as this concentration is consistent with the results of septic shock blood experiments. We performed ozone insufflations in a "sealed environment". The total number of insuffla- tions for each experiment ranged from one to four. The gas concentration was maintained at $80 \mathrm{mcg} / \mathrm{ml}$. We con- firmed the bactericidal activity of ozone on saline for all the bacterial strains. Experiments in broth revealed no changes in the bacterial growth. Ozone is primarily bactericidal against $E$. coli and bacteriostatic on $P$. aerugi- nosa, S. aureus and $E$. faecalis on whole blood. This study confirms the bactericidal efficacy of topical ozone ap- plications and supports the need for further evaluations of the therapeutic potential of major ozone autohemo- therapy. The results in $E$. coli promote further investigations of ozone activity on other Enterobacteriaceae and its potential use in the treatment of urinary infections. In general, these results suggest that ozone-therapy might be an alternative therapy to overcome antibiotic resistance.

\section{KEYWORDS}

Ozone; Bactericidal Activity; in Vitro; Media; Therapeutic Treatment

\section{Introduction}

The microbicidal activity of ozone has been demonstrated since the late 1800 . The first municipal water purification plant dates back to 1906. On June 26, 2001, the US Food and Drug Administration (FDA) formally approved the use of ozone (gaseous phase and ozonized water) as an antimicrobial agent for the treatment, storage and preservation of food products [1].

Ozone is the most powerful oxidizing agent, showing ten times the effectiveness of chlorine, and it's currently used to potabilize water [2-4], disinfect swimming pool water [5] and decontaminate bioclean rooms [6].

Ozone bactericidal activity seems to be primarily result-

\footnotetext{
"Corresponding author.
}

ing from direct oxidative damage and the effects of ozone have been tested on different bacterial strains, including E. coli, Salmonella sp., S. aureus and Bacillus subtilis [718].

Using electron microscopy analysis, Thanomsub et al. showed the destruction of the bacterial membrane with consequent cell lysis [19]. The treatment of Bacillus subtilis spores with various oxidizing agents (including ozone) damages the inner membrane, making the spores more sensitive to subsequent thermal and osmotic stresses, with the increased rapid penetration of methylamine within the core [20]. The literature also confirms the synergic action of ozone with antibiotic therapy in vivo [21-26].

The in vitro ozone bactericidal activity is compromised when applied to blood and blood derivatives [27]. 
The aim of this study is to evaluate the ozone bactericidal activity on different bacterial strains and media under different circumstances.

\section{Materials and Methods}

\subsection{Microorganisms and Media}

These experiments were divided into three phases according to the suspension media used: saline, nutrient broth (BHI) and whole blood.

We focused our study on the four multi-resistant bacterial strains frequently found in nosocomial sepsis [2833]. The following bacterial strains were isolated from clinical samples obtained from patients at the Neurosurgery Intensive Care Unit, suspended in glycerol and frozen at $-80^{\circ} \mathrm{C}$ :

- Methicillin-resistant Staph. aureus;

- Ent. faecalis;

- ESBL-positive E. coli;

- MDR Ps. aeruginosa.

The preparation of the bacterial strains was performed using the following steps:

1) Thawing of the bacterial strain for testing;

2) Seeding culture medium Trypticase Soy Agar (TSA);

3) Incubation at $37^{\circ} \mathrm{C}$ for 18 - 24 hours;

4) Suspension of the bacterial strains in saline and dilution until reaching 0.2 MF (McFarland);

5) Using a drop (0.02 $\mathrm{ml})$ of the bacterial suspension;

6) Inoculating into $2.5 \mathrm{ml}$ of the selected medium.

\subsection{Ozone Generation}

A Medica-srl machine, model E80, was used to generate medical ozone (Ozonline International, Medica S.r.l. Via Sante Vincenzi, 48 - 40138 Bologna

Italy) from oxygen and electricity. The machine converts medical oxygen into a mixture of $\mathrm{O}_{3}(0.05 \%)$ and $\mathrm{O}_{2}$ (99.95\%) through an electrochemical process.

The Medica-srl machine is equipped with a photometer, calibrated according to the classic iodometric titration of ozone, and a voltage system which regulates the concentration within a range from 5 to $80 \mu \mathrm{g} / \mathrm{ml}$.

In all the experiments, we used an ozone concentration of $80 \mu \mathrm{g} / \mathrm{ml}$, corresponding to the maximum concentration within the therapeutic range recommended in vivo [34-38].

The volume of the $\mathrm{O}_{2} / \mathrm{O}_{3}$ gas mixture used for each insufflation was $6 \mathrm{ml}$, corresponding to $480 \mu \mathrm{g}$ of ozone.

\subsection{Treatment of the Bacterial Strains with Ozone}

2.3.1. Suspension Medium: Saline

The four bacterial strains were suspended in saline and diluted until reaching $0.2 \mathrm{MF}$ in a final volume of $2.5 \mathrm{ml}$ for each suspension. The obtained bacterial suspensions were sown onto TSA culture medium (Bio-Mérieux Italia) as $\left(\mathrm{T}_{0}\right)$. We standardized the inoculum using a calibrated loop of $10 \mu \mathrm{l}$ and seeding in four quadrants.

We placed a 21-gauge needle (Troge/Hamburg), premounted with a three-way cock (Axel S.r.l. connector), on the tubes containing the bacterial suspensions (BD 7-ml Vacutainer Red tube, Belliver Industrial Estate, Plymouth), thereby avoiding any leakage of the gas during the insufflation ("insufflation in closed tube").

Because of excessive pressure, the insufflation could open the tubes. To avoid this problem, we aspirated the air from the tubes using a 60-ml syringe (Luer Lock Omnifix/B. Braun) for a total of $360 \mathrm{ml}$, creating a vacuum.

We proceeded with the insufflation of $6 \mathrm{ml}$ of $\mathrm{O}_{2} / \mathrm{O}_{3}$ mixture.

This procedure was applied in all experiments.

The tubes were subsequently shaken in a monodirectional oscillator for 40 minutes.

The experiment was terminated with a second seeding $\left(\mathrm{T}_{1}\right)$.

\subsubsection{Suspension Medium: Brain Heart Infusion (BHI)}

The bacterial strains were suspended in saline, diluted until 0.2 MF and suspended in $2.5 \mathrm{ml}$ of BHI (Bio-Mérieux Italia).

The bacterial suspensions were sown onto TSA culture medium (Bio-Mérieux Italia) as $\left(\mathrm{T}_{0}\right)$.

We proceeded with the insufflation of $6 \mathrm{ml}$ of $\mathrm{O}_{2} / \mathrm{O}_{3}$ mixture.

The tubes were subsequently shaken in a monodirectional oscillator for 40 minutes.

The experiment was terminated with a second seeding $\left(\mathrm{T}_{1}\right)$.

\subsubsection{Suspension Medium: Whole Blood}

We performed the same procedure on medium containing the fresh whole blood of healthy donors. The blood was collected using a 21-gauge butterfly needle (Pic Indolor, Mirage, Artsana S.p.a. Grandate, CO, Italy) and BD Vacutainer Light Blue tubes containing citrate (Belliver Industrial Estate, Plymouth).

We performed seven different experiments:

1) We inoculated the bacterial suspensions in $2.5 \mathrm{ml}$ of whole blood; the obtained bacterial suspensions were subsequently sown onto TSA culture media (Bio-Mérieux Italia) as $\left(\mathrm{T}_{0}\right)$.

The experiment continued, according to the following steps:

- Insufflation of the $\mathrm{O}_{2} / \mathrm{O}_{3}$ mixture;

- Mechanical agitation for 5 minutes;

- Second seeding $\left(\mathrm{T}_{1}\right)$; 
- Mechanical agitation for 20 minutes;

- Third seeding $\left(\mathrm{T}_{2}\right)$;

- Mechanical agitation for 20 minutes; and

- Fourth seeding $\left(\mathrm{T}_{3}\right)$.

Ozone: $480 \mu \mathrm{g} \times 1=480 \mu \mathrm{g}$.

Total time of mechanical agitation: 45'.

2) We inoculated the bacterial suspensions in $2.5 \mathrm{ml}$ of whole blood; the obtained bacterial suspensions were subsequently sown onto TSA culture media (Bio-Mérieux Italia) as $\left(\mathrm{T}_{0}\right)$.

The experiment continued according to the following steps:

- Insufflation of the $\mathrm{O}_{2} / \mathrm{O}_{3}$ mixture;

- Mechanical agitation for 5 minutes;

- Second seeding $\left(T_{1}\right)$;

- Second insufflation of the $\mathrm{O}_{2} / \mathrm{O}_{3}$ mixture;

- Mechanical agitation for 40 minutes; and

- Third seeding $\left(\mathrm{T}_{2}\right)$.

Ozone: $480 \mu \mathrm{g} \times 2=960 \mu \mathrm{g}$.

Total time of mechanical agitation: 45'.

3) We inoculated the bacterial suspensions in $2.5 \mathrm{ml}$ of whole blood, and the obtained bacterial suspensions were subsequently sown onto TSA culture media (Bio-Mérieux Italia) as $\left(\mathrm{T}_{0}\right)$.

The experiment continued according to the following steps:

- Insufflation of the $\mathrm{O}_{2} / \mathrm{O}_{3}$ mixture;

- Mechanical agitation for 5 minutes;

- Second seeding $\left(\mathrm{T}_{1}\right)$;

- Second insufflation of the $\mathrm{O}_{2} / \mathrm{O}_{3}$ mixture;

- Mechanical agitation for 20 minutes;

- Third insufflation of the $\mathrm{O}_{2} / \mathrm{O}_{3}$ mixture;

- Mechanical agitation for 20 minutes; and

- Third seeding $\left(\mathrm{T}_{2}\right)$.

Ozone: $480 \mu \mathrm{g} \times 3=1440 \mu \mathrm{g}$.

Total time of mechanical agitation: 45 '.

4) We inoculated the bacterial suspensions in $2.5 \mathrm{ml}$ of whole blood, and the obtained bacterial suspensions were subsequently sown onto TSA culture media (Bio-Mérieux Italia) as $\left(\mathrm{T}_{0}\right)$.

The experiment continued according to the following steps:

- Insufflation of the $\mathrm{O}_{2} / \mathrm{O}_{3}$ mixture;

- Mechanical agitation for 5 minutes;

- Second seeding $\left(\mathrm{T}_{1}\right)$;

- Second insufflation of the $\mathrm{O}_{2} / \mathrm{O}_{3}$ mixture;

- Mechanical agitation for 20 minutes;

- Third seeding $\left(\mathrm{T}_{2}\right)$;

- Mechanical agitation for 20 minutes;

- Fourth seeding $\left(\mathrm{T}_{3}\right)$;

- Mechanical agitation for 20 minutes; and

- Fifth seeding $\left(\mathrm{T}_{4}\right)$.

Ozone: $480 \mu \mathrm{g} \times 1=480 \mu \mathrm{g}$.

Total time of mechanical agitation: 65’.
5) We inoculated the bacterial suspensions in $2.5 \mathrm{ml}$ of whole blood, and the obtained bacterial suspensions were subsequently sown onto TSA culture media (Bio-Mérieux Italia) as $\left(\mathrm{T}_{0}\right)$.

The experiment continued according to the following steps:

- Insufflation of the $\mathrm{O}_{2} / \mathrm{O}_{3}$ mixture;

- Mechanical agitation for 5 minutes;

- Second seeding $\left(\mathrm{T}_{1}\right)$;

- Mechanical agitation for per 20 minutes;

- Third seeding $\left(\mathrm{T}_{2}\right)$;

- Second insufflation of the $\mathrm{O}_{2} / \mathrm{O}_{3}$ minutes;

- Mechanical agitation for 20 minutes;

- Fourth seeding $\left(\mathrm{T}_{3}\right)$;

- Third insufflation of the $\mathrm{O}_{2} / \mathrm{O}_{3}$ mixture;

- Mechanical agitation for 20 minutes;

- Fourth insufflation of the $\mathrm{O}_{2} / \mathrm{O}_{3}$ mixture;

- Mechanical agitation for 20 minutes; and

- Fifth seeding $\left(\mathrm{T}_{4}\right)$.

Ozone: $480 \mu \mathrm{g} \times 4=1920 \mu \mathrm{g}$.

Total time of mechanical agitation: 85 '.

6) We inoculated the bacterial suspensions in $2.5 \mathrm{ml}$ of whole blood, and the obtained bacterial suspensions were subsequently sown onto TSA culture media (Bio-Mérieux Italia) as $\left(\mathrm{T}_{0}\right)$.

The experiment continued according to the following steps:

- Insufflation of the $\mathrm{O}_{2} / \mathrm{O}_{3}$ mixture;

- Mechanical agitation for 5 minutes;

- Second seeding $\left(\mathrm{T}_{1}\right)$;

- Mechanical agitation for 40 minutes;

- Third seeding $\left(\mathrm{T}_{2}\right)$;

- Second insufflation of the $\mathrm{O}_{2} / \mathrm{O}_{3}$ mixture, consistent with the resumption of the bacterial growth;

- Mechanical agitation for 20 minutes; and

- Fourth seeding $\left(\mathrm{T}_{3}\right)$.

Ozone: $480 \mu \mathrm{g} \times 2=960 \mu \mathrm{g}$.

Total time of mechanical agitation: 65 '.

7) We inoculated the bacterial suspensions in $2.5 \mathrm{ml}$ of whole blood, and the obtained bacterial suspensions were subsequently sown onto TSA culture media (Bio-Mérieux Italia) as $\left(\mathrm{T}_{0}\right)$.

The experiment continued according to the following steps:

- Insufflation of the $\mathrm{O}_{2} / \mathrm{O}_{3}$ mixture;

- Mechanical agitation for 5 minutes;

- Second seeding $\left(\mathrm{T}_{1}\right)$;

- Second insufflation of the $\mathrm{O}_{2} / \mathrm{O}_{3}$ mixture;

- Mechanical agitation for 5 minutes;

- Third insufflation of the $\mathrm{O}_{2} / \mathrm{O}_{3}$ mixture;

- Mechanical agitation for 5 minutes;

- Fourth insufflation of the $\mathrm{O}_{2} / \mathrm{O}_{3}$ mixture;

- Mechanical agitation for 5 minutes; 
- Third seeding $\left(\mathrm{T}_{2}\right)$;

- Mechanical agitation for 20 minutes;

- Fourth seeding $\left(\mathrm{T}_{3}\right)$;

- Mechanical agitation for 40 minutes; and

- Fifth seeding (T4).

Ozone: $480 \mu g \times 4=1920 \mu g$.

Total time of mechanical agitation: 80 '.

Before and after each experiment on whole blood, we performed a complete blood count.

All experiments, regardless of the suspension medium, were consistent with a control bacterial growth curve obtained without ozone.

\subsection{Statistical Analysis}

The results were expressed as the means \pm SD of three independent measurements for each experiment. The statistical evaluations were performed using the statistical software SPSS ver. 10. Significance was defined as a $P$ value $<0.05$.

\section{Results}

\subsection{Suspension Medium: Saline}

After contact with the $\mathrm{O}_{2} / \mathrm{O}_{3}$ mixture, we observed a total reduction of the bacterial load and the absence of
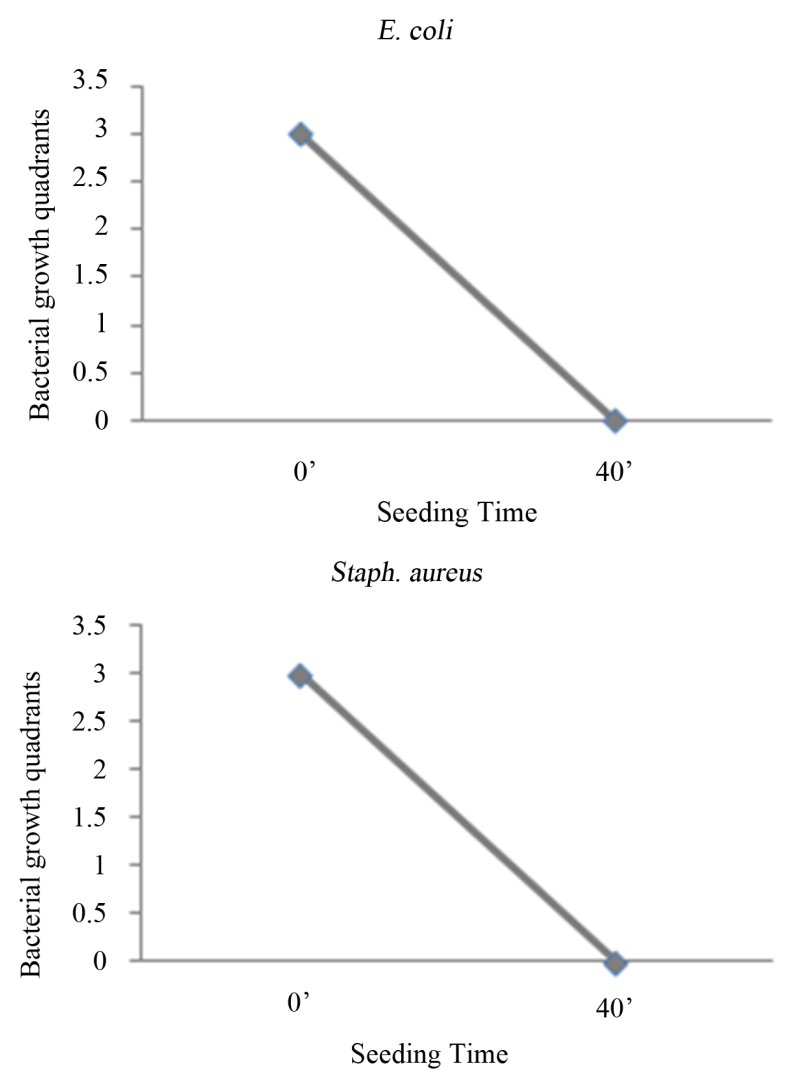

growth for all four bacterial strains under examination (Figure 1).

\subsection{Suspension Medium: Whole Blood}

We performed seven experiments, adding ozone to the bacterial suspensions to verify the total dosage and intervals between insufflations.

Experiment I - Ozone: $480 \mu \mathrm{g} \times 1$; total time of mechanical agitation: 45'.

Staph. aureus, Ps. aeruginosa, Ent. faecalis: reduction of bacterial growth at $\mathrm{T}_{1}\left(5^{\prime}\right)$ and bacterial resumption at $\mathrm{T}_{3}$ (45'), except for Staph. aureus which showed bacteriostatic activity.

E. coli: reduction of bacterial growth at $\mathrm{T}_{1}\left(5^{\prime}\right)$ and total absence of colonies at $T_{2}$ and $T_{3}$. Bactericidal activity (Figure 2).

Experiment II - Ozone: $480 \mu \mathrm{g} \times 2$; total time of mechanical agitation: 45'.

Staph. aureus, Ps. aeruginosa, Ent. faecalis: Bacteriostatic activity.

E. coli: reduction of the bacterial growth at $\mathrm{T}_{1}\left(5^{\prime}\right)$ and total absence of colonies at $\mathrm{T}_{2}$. Bactericidal activity (Figure 3).

Experiment III - Ozone: $480 \mu \mathrm{g} \times 3$; total time of mechanical agitation: 45’.

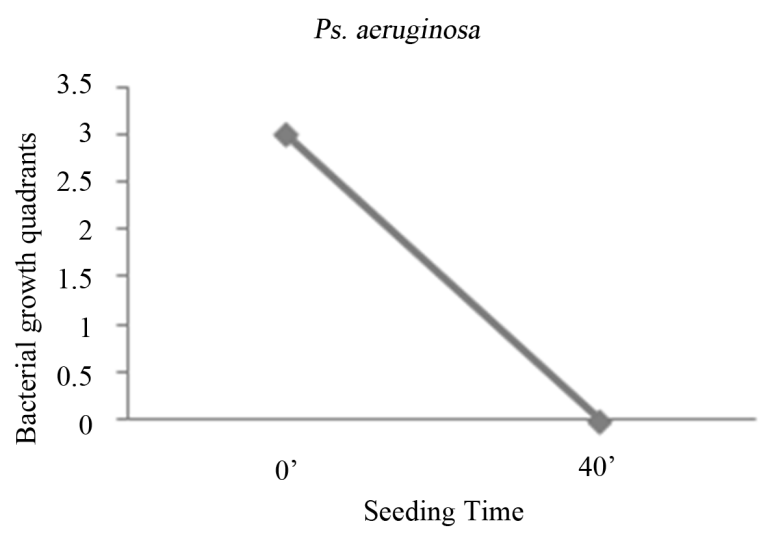

Ent. faecalis

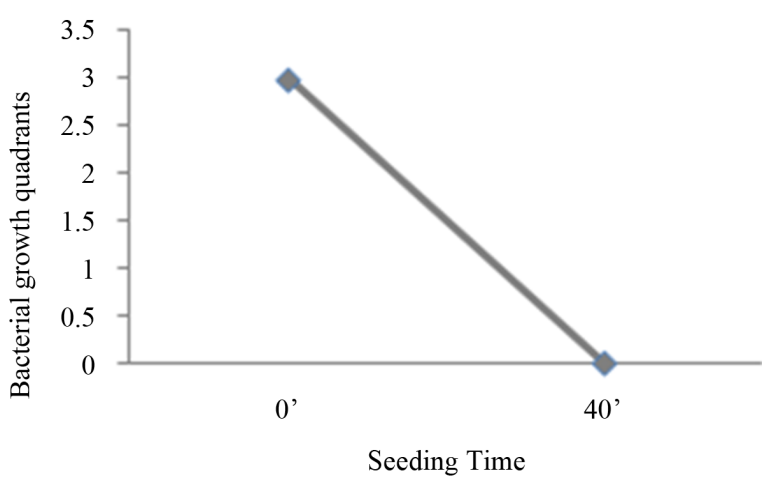

Figure 1. Experience on saline: seeding at $\mathrm{T}_{0}$, with $\mathrm{O}_{3}$ treatment, mechanical agitation for 40 minutes, and subsequent seeding at $T_{1}$. $T_{0}\left(0^{\prime}\right) ; O_{3}\left(0^{\prime}\right) ; T_{1}\left(40^{\prime}\right)$. Ozone: $480 \mu \mathrm{g} \times 1$. Total time of mechanical agitation: $40^{\prime}$. 


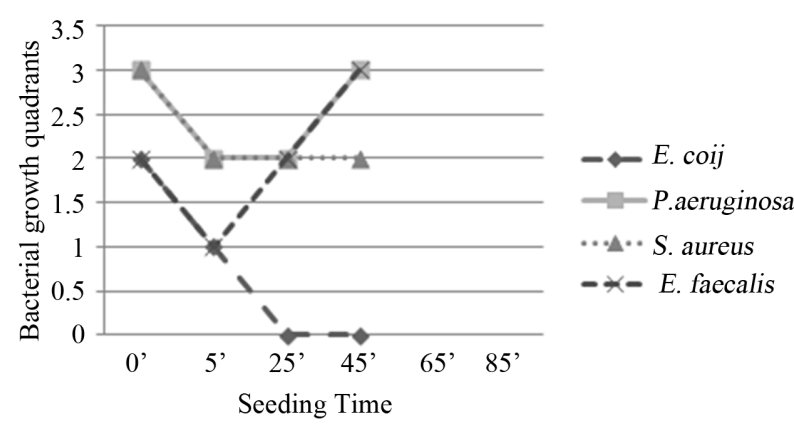

Figure 2. Experiment I on whole blood: seeding $\mathbf{T}_{\mathbf{0}}, \mathbf{O}_{3}$, mechanical agitation for 5 minutes, seeding $T_{1}$, mechanical agitation for 20 minutes, seeding $T_{2}$, mechanical agitation for 20 minutes, seeding $T_{3}$. $T_{0}\left(0^{\prime}\right) ; O_{3}\left(0^{\prime}\right) ; T_{1}\left(5^{\prime}\right) ; T_{2}\left(25^{\prime}\right) ; T_{3}$ (45'). Ozone: $480 \mu \mathrm{g} \times 1$. Total time of mechanical agitation: 45'.

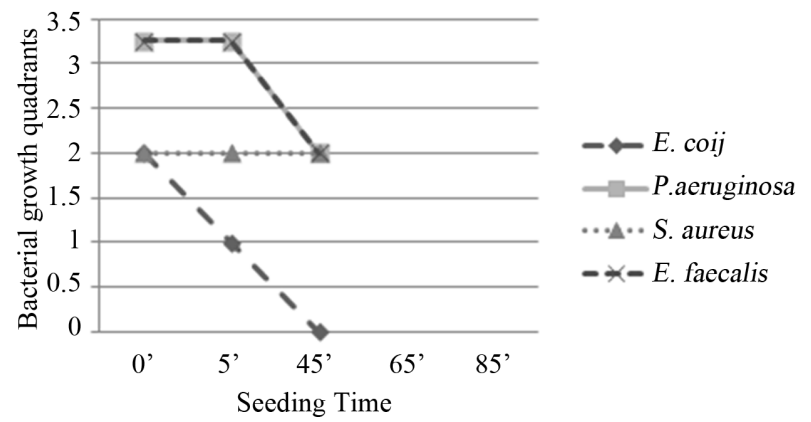

Figure 3. Experiment II on whole blood: seeding $\mathbf{T}_{\mathbf{0}}, \mathbf{O}_{3}$, mechanical agitation for 5 minutes, seeding $T_{1}, O_{3}$, mechanical agitation for 40 minutes, seeding $T_{2} . T_{0}\left(0^{\prime}\right) ; O_{3}\left(0^{\prime}\right) ; T_{1} \rightarrow$ $\mathrm{O}_{3}\left(5^{\prime}\right)$; $\mathrm{T}_{2}$ (45'). Ozone: $480 \mu \mathrm{g} \times 2$. Total time of mechanical agitation: 45 '.

Staph. aureus and Ent. faecalis remained in the two quadrants in each seeding, while Ps. aeruginosa showed a growth reduction at $\mathrm{T}_{1}\left(5^{\prime}\right)$ and also remained in one quadrant at $\mathrm{T}_{2}\left(45^{\prime}\right)$. Bacteriostatic activity.

E. coli: reduction of bacterial growth at $\mathrm{T}_{1}\left(5^{\prime}\right)$ and total absence of colonies at $\mathrm{T}_{2}\left(45^{\prime}\right)$. Bactericidal activity (Figure 4).

Experiment IV - Ozone: $480 \mu \mathrm{g} \times 1$; total time of mechanical agitation: 65'.

Staph. aureus and Ps. aeruginosa: a reduction of bacterial growth at $\mathrm{T}_{2}$ (25') which extended to $\mathrm{T}_{3}$ (45'). Bacteriostatic activity.

Ent. faecalis: although a higher susceptibility to ozone than the first two bacteria was observed, these bacteria showed an evident resumption of growth at $\mathrm{T}_{4}$ (65').

E. coli: progressive reduction of the bacterial growth from $\mathrm{T}_{0}$ to $\mathrm{T}_{3}\left(45^{\prime}\right.$ ). Bactericidal activity (Figure 5 ).

Experiment $\mathbf{V}$ - Ozone: $480 \mu \mathrm{g} \times 4$; total time of mechanical agitation: 85'.

Staph. aureus and Ent. faecalis: reduction of bacterial growth for both bacteria, respectively at $\mathrm{T}_{2}\left(25^{\prime}\right)$ and $\mathrm{T}_{1}$ (5') with evident resumption at $\mathrm{T}_{4}\left(85^{\prime}\right)$.
$P$. aeruginosa and E. coli: showed a progressive reduction in bacterial growth from $\mathrm{T}_{0}$ to $\mathrm{T}_{3}\left(45^{\prime}\right)$ which did not increase from $T_{3}\left(45^{\prime}\right)$ to $T_{4}$ (85'). Bacteriostatic activity (Figure 6).

Experiment VI - Ozone: $480 \mu \mathrm{g} \times 2$; total time of mechanical agitation: 65'.

Staph. aureus, Ps. aeruginosa and Ent. faecalis: further reduction of bacterial growth for all bacteria, respectively at $T_{2}\left(45^{\prime}\right), T_{1}\left(5^{\prime}\right)$ and $T_{3}\left(65^{\prime}\right)$, and progressive reduction of the bacterial growth in subsequent seedings. Bactericidal activity.

E. coli: evident reduction of bacterial growth at $\mathrm{T}_{1}\left(5^{\prime}\right)$ and total absence of colonies at $\mathrm{T}_{2}\left(45^{\prime}\right)$ and $\mathrm{T}_{3}\left(65^{\prime}\right)$. Bactericidal activity (Figure 7).

Experiment VII - Ozone: $480 \mu \mathrm{g} \times 4$; total time of mechanical agitation: 80 '.

The results for Staph. aureus and Ps. aeruginosa were similar: after an evident reduction at $\mathrm{T}_{2}$, the bacterial growth resumed.

Ent. faecalis: bacterial growth was observed in three quadrants at $\mathrm{T}_{0}$ and in two quadrants at $\mathrm{T}_{1}\left(5^{\prime}\right)$; the growth returned in three quadrants at $\mathrm{T}_{2}\left(20^{\prime}\right)$ and remained constant until the last seeding $\left(\mathrm{T}_{4}: 80\right.$ '). Bacteriostatic activity.

E. coli: the evident reduction of bacterial growth at $\mathrm{T}_{1}$ (5') and total absence of colonies in subsequent seedings. Bactericidal activity (Figure 8).

The blood counts showed no significant changes.

The curves of the control bacterial growth showed a progressive increase in the bacterial growth.

\section{Discussion}

The study was divided into three phases, according to the suspension medium used for the bacterial cultures (saline, BHI and whole blood), to understand the interaction between the ozone, bacterium and the suspension medium. Indeed, the milieu in which microbes are present determines the effectiveness and outcome of the ozone treatment [39].

As shown in previous studies $[7,11,16]$, we confirmed the ozone bactericidal activity on all bacterial strains when suspended in saline. Interestingly enough, ozone loses bactericidal activity with BHI suspension medium.

The results are interesting and discordant when the suspension medium is whole blood. Burgassi et al. observed that fresh plasma (as a biological substance with antioxidant systems), compromises ozone bactericidal activity.

Moreover, these authors suggested the incompatibility of using whole blood because it coagulates in the presence of a bacterial suspension [27].

To overcome this technical problem, we used tubes containing citrate, the same anticoagulant present in the bags for major ozone autohemotherapy $\left(\right.$ AHT $\left.-\mathrm{O}_{3}\right)$. 


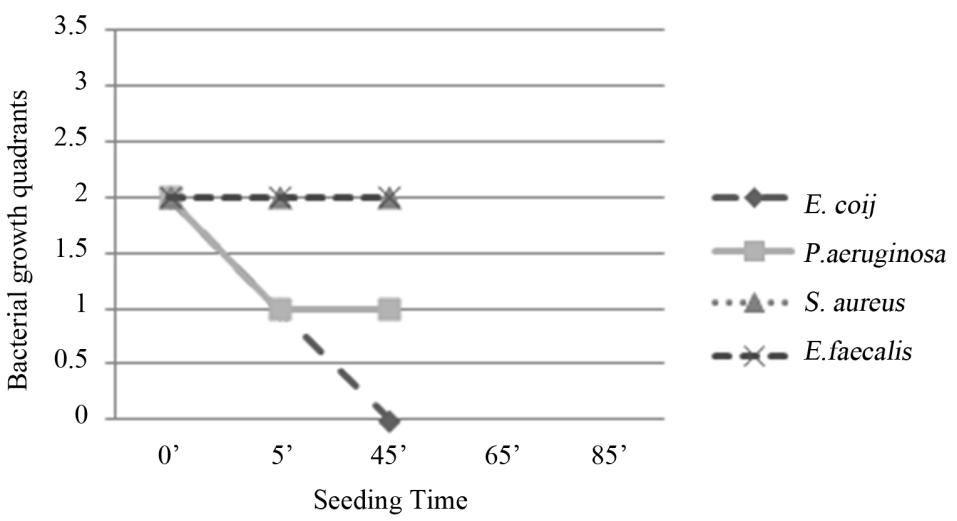

Figure 4. Experiment III on whole blood: seeding $\mathbf{T}_{0}, \mathbf{O}_{3}$, mechanical agitation for 5 minutes, seeding $\mathbf{T}_{1}$, $\mathbf{O}_{3}$, mechanical agitation for 20 minutes, $O_{3}$, mechanical agitation for 20 minutes, seeding $T_{2}$. $T_{0}\left(0^{\prime}\right)$; $O_{3}\left(0^{\prime}\right)$; $T_{1} \rightarrow O_{3}\left(5^{\prime}\right)$; $O_{3}\left(25^{\prime}\right)$; $T_{2}$ (45'). Ozone: $480 \mu \mathrm{g} \times 3$. Total time of mechanical agitation: 45 '.

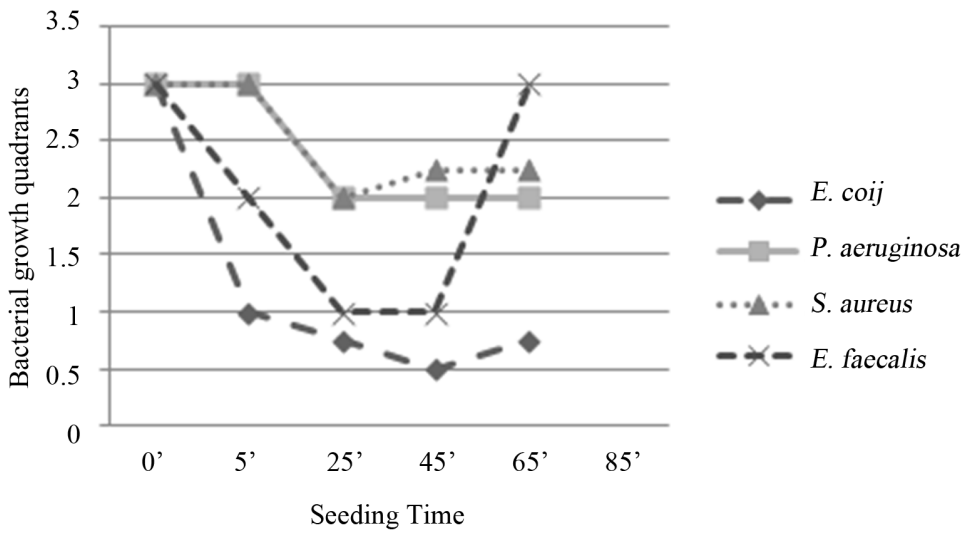

Figure 5. Experiment IV on whole blood: seeding $\mathbf{T}_{0}, \mathbf{O}_{3}$, mechanical agitation for 5 minutes, seeding $T_{1}$, mechanical agitation for 20 minutes, seeding $T_{2}$, mechanical agitation for 20 minutes, seeding $T_{3}$, mechanical agitation for 20 minutes, seeding $T_{4}$. $\mathrm{T}_{0}\left(0^{\prime}\right) ; \mathrm{O}_{3}\left(0^{\prime}\right) ; \mathrm{T}_{1}\left(5^{\prime}\right) ; \mathrm{T}_{2}\left(25^{\prime}\right) ; \mathrm{T}_{3}\left(45^{\prime}\right) ; \mathrm{T}_{4}\left(65^{\prime}\right)$. Ozone: $480 \mu \mathrm{g} \times 1$. Total time of mechanical agitation: 65’.

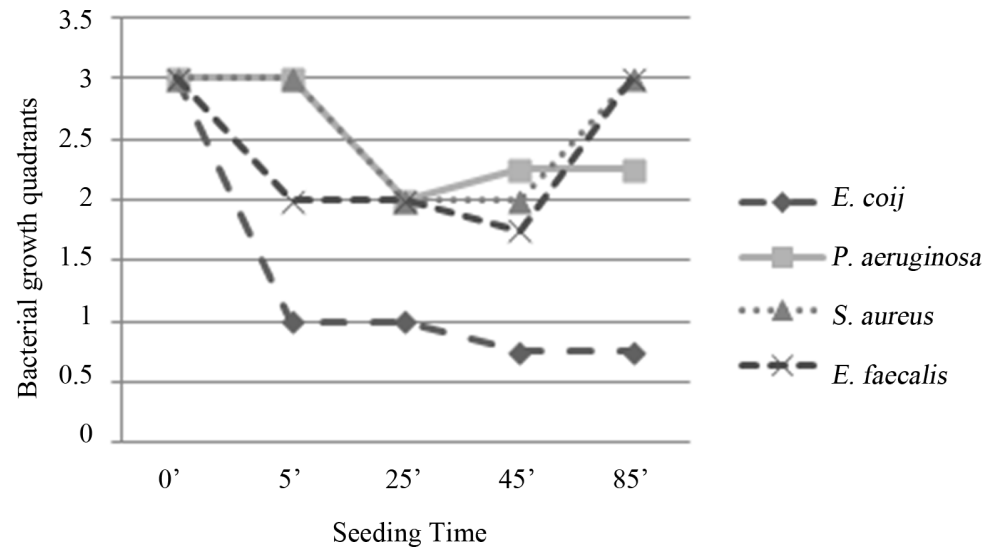

Figure 6. Experiment $\mathrm{V}$ on whole blood: seeding $\mathrm{T}_{\mathbf{0}}, \mathrm{O}_{3}$, mechanical agitation for $\mathbf{5}$ minutes, seeding $\mathrm{T}_{1}$, mechanical agitation for 20 minutes, seeding $T_{2}, O_{3}$, mechanical agitation for 20 minutes, seeding $T_{3}, O_{3}$, mechanical agitation for 20 minutes, $O_{3}$, mechanical agitation for 20 minutes, $T_{4}$. $T_{0}\left(0^{\prime}\right.$ ); $O_{3}\left(0^{\prime}\right.$ ); $T_{1}\left(5^{\prime}\right)$; $T_{2} \rightarrow O_{3}\left(25^{\prime}\right.$ ); $T_{3} \rightarrow O_{3}\left(45^{\prime}\right.$ ); $O_{3}\left(65^{\prime}\right.$ ); $T_{4}\left(85^{\prime}\right)$. Ozone: 480 $\mu \mathrm{g} \times 4$. Total time of mechanical agitation: 85 '.

Compared to the results reported in the literature, our study on whole blood shows that the single insufflation with an $\mathrm{O}_{2} / \mathrm{O}_{3}$ mixture is sufficient to achieve a bacteri- cidal effect on E. coli. We also found that a second insufflation was essential for improving the results; specifically, the most encouraging results were obtained in ex- 


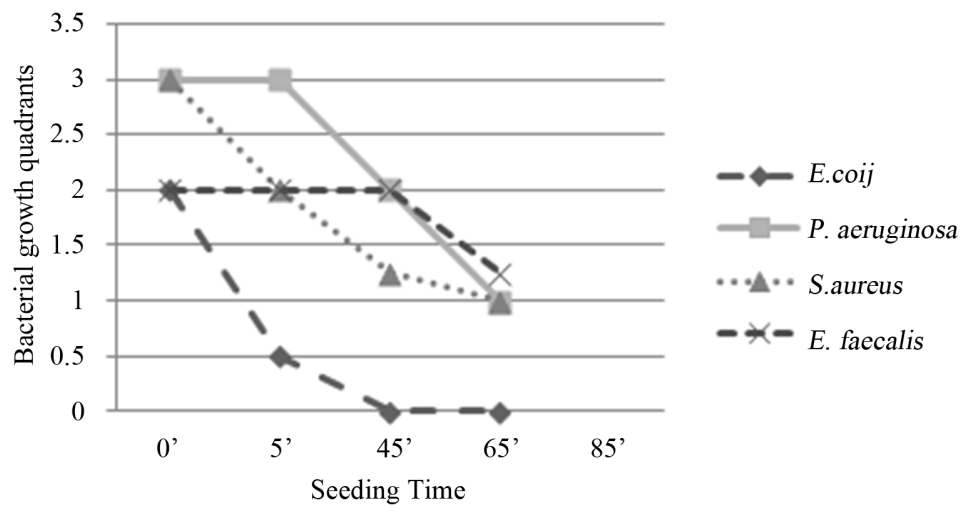

Figure 7. Experiment VI on whole blood: seeding $T_{0}, O_{3}$, mechanical agitation for 5 minutes, seeding $T_{1}$, mechanical agitation for 40 minutes, seeding $T_{2}, O_{3}$, mechanical agitation 20 minutes, seeding $T_{3}$. $T_{0}\left(0^{\prime}\right)$; $O_{3}\left(0^{\prime}\right)$; $T_{1}\left(5^{\prime}\right)$; $T_{2} \rightarrow O_{3}\left(45^{\prime}\right.$ ); $T_{3}\left(65^{\prime}\right.$ ). Ozone: $480 \mu \mathrm{g} \times 2$. Total time of mechanical agitation: 65'.

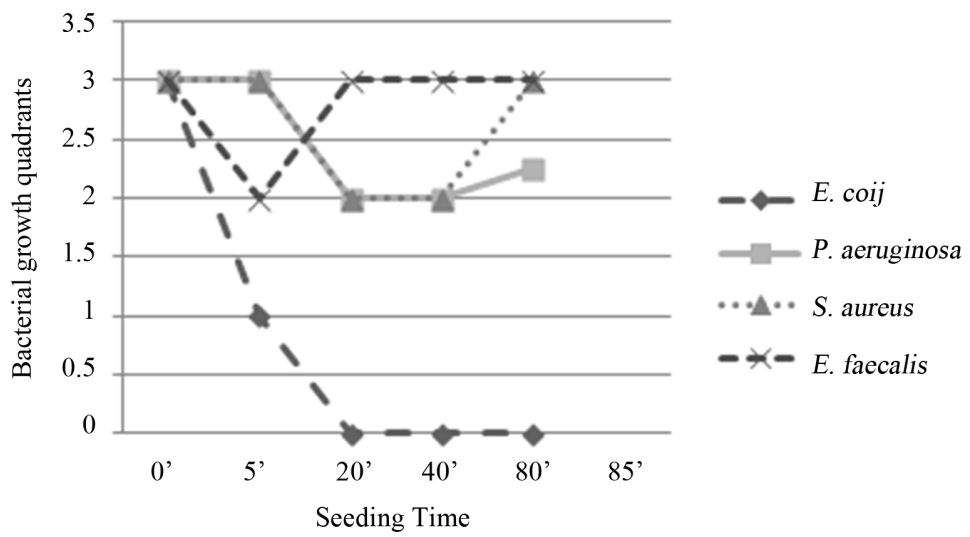

Figure 8. Experiment VII on whole blood: seeding $\mathrm{T}_{0}, \mathrm{O}_{3}$, mechanical agitation for 5 minutes, seeding $\mathrm{T}_{1}, \mathrm{O}_{3}$, mechanical agitation for 5 minutes, $\mathrm{O}_{3}$, mechanical agitation for 5 minutes, $\mathrm{O}_{3}$, mechanical agitation for 5 minutes, seeding $\mathrm{T}_{2}$, mechanical agitation for 20 minutes, seeding $T_{3}$, mechanical agitation for 40 minutes, seeding $T_{4} . T_{0}\left(0^{\prime}\right) ; O_{3}\left(0^{\prime}\right) ; T_{1}\left(5^{\prime}\right) ; O_{3}\left(10^{\prime}\right) ; O_{3}$ $\left(15^{\prime}\right) ; O_{3}\left(20^{\prime}\right) ; T_{3}\left(40^{\prime}\right) ; T_{4}\left(80^{\prime}\right)$. Ozone: $480 \mu \mathrm{g} \times 4$. Total time of mechanical agitation: $80^{\prime}$.

periment VI, where we performed a second insufflation at 45 minutes after the first. We observed that the bacterial growth typically resumed after approximately 40 minutes from the first exposure to the ozone oxidative insult, suggesting that the best results were obtained in experiment VI.

Although additional ozone insufflations prolonged bactericidal activity (Staph. aureus, Ent. faecalis, Ps. aeruginosa), the effects of these treatments were not significantly different from those obtained in the experiments with only two insufflations.

Based on the differential results obtained on whole blood between E. coli and Ps. aeruginosa, and the failure of the experiments on broth culture, suggested that the mechanism of ozone, contrary to the literature $[19,20]$, could also have a metabolic basis. On the other hand, changes in the size and morphology of the colonies, observed in all the bacterial strains after exposure to ozone, confirm the oxidative mechanism.

The bactericidal activity on E. coli, contrasts with the increased effectiveness of ozone against Gram-positive bacteria [19]. The primary target of ozone on E. coli is the sulfhydryl group in the bacterial membrane [40]. Thus, we confirmed the correlation between ozone bactericidal activity and membrane permeability, which is specific for each microorganism [39].

The results of our study on whole blood represents an important confirmation of the ozone bactericidal activity in the topical treatment of wounds, and the daily persistence of topical ozone preparations kills even the most resistant bacteria $[25,41]$.

The in vitro results were not consistent with the observations of $\mathrm{AHT}-\mathrm{O}_{3}$ in vivo, except for the portion of blood directly exposed to ozone. In fact, these results are consistent with those of Burgassi et al. [27], showing that the AHT enriched with ozone, even at highest ozone concentration $(80 \mu \mathrm{g} / \mathrm{ml})$, is not able to oxidize and destroy circulating bacteria in the blood.

However, the evaluation of the ozone bactericidal activity on whole blood performed in the present study in- 
volves exclusively its direct action in vitro. While in vivo, AHT enriched with ozone induces a series of effects that might also be indirectly useful in the treatment of infections, such as: immune modulation [42-48], antioxidant systems activation [49-52] and improvement of the microcirculation [53-56].

To clarify the mechanism of ozone, it would be useful to examine its affects on other Enterobacteriaceae (suspension medium: whole blood), such as Serratia and Klebsiella, and Aspergillus. Indeed, Aspergillus produces large colonies whose variations in size or color might be an important index for metabolic alterations.

In conclusion, we confirmed the bactericidal efficacy of topical ozone preparations, according to the evidence of antibody-catalyzed ozone formation in bacterial killing [57], and suggest the need for further evaluations of the therapeutic potential of AHT- $\mathrm{O}_{3}$.

\section{Conclusion}

Further in vitro investigation on whole blood might reveal the synergic action between traditional antibiotics and ozone treatment, and might provide the basis for developing successive studies in vivo in patients affected through multidrug resistant nosocomial infections.

\section{Conflict of Interest}

The authors declare that they have no conflict of interest, neither commercial nor financial, in any of the products described in this article.

\section{REFERENCES}

[1] Safe Practices for Food Processes, Chapter V, "Methods to Reduce/Eliminate Pathogens from Produce and FreshCut Produce,” US Food and Drug Administration. www.fda.gov/food/foodscienceresearch/safepracticesforf oodprocesses/ucm091363.htm

[2] D. S. Boyce, O. J. Sproul and C. E. Buck, "The Effect of Bentonite Clay on Ozone Disinfection of Bacteria and Viruses in Water,” Water Research, Vol. 15, No. 6, 1981, pp. 759-767. http://dx.doi.org/10.1016/0043-1354(81)90169-X

[3] W. H. Glaze, "Drinking Water Treatment with Ozone," Environmental Science \& Technology, Vol. 21, No. 3, 1987, pp. 224-230. http://dx.doi.org/10.1021/es00157a001

[4] A. Joss, H. Siegrist and T. A. Ternes, “Are We about to Upgrade Wastewater Treatment for Removing Organic Micropollutans?” Water Science and Technology, Vol. 57, No. 2, 2008, pp. 251-255. http://dx.doi.org/10.2166/wst.2008.825

[5] T. Glauner, P. Waldmann, F. H. Frimmel and C. Zwiener, "Swimming Pool Water-Fractionation and Genotoxicological Characterization of Organic Constituents," Water Research, Vol. 39, No. 18, 2005, pp. 4494-4502. http://dx.doi.org/10.1016/j.watres.2005.09.005

[6] T. Masaoka, Y. Kubota, S. Namiuchi, T. Takubo, T. Ueda, H. Shibata, H. Nakamura, K. Yoshitake, H. Doi and T. Kamiki, "Ozone Decontamination of Bioclean Rooms," Applied and Environmental Microbiology, Vol. 43, No. 3, 1982, pp. 509-513.

[7] A. Baysan, R. A. Whiley and E. Lynch, “Antimicrobial Effect of a Novel Ozone-Generating Device on Micro-Organisms Associated with Primary Root Carious Lesions in Vitro," Caries Research, Vol. 34, No. 6, 2000, pp. 498501. http://dx.doi.org/10.1159/000016630

[8] D. Bialoszewski, E. Bocian, B. Bukowska, M. Czajkowska, L. B. Sokół and S. Tyski, "Antimicrobial Activity of Ozonated Water,” Medical Science Monitor, Vol. 16, No. 9, 2010, pp. 71-75.

[9] A. Castillo, P. Galindo Moreno, G. Avila, M. Valderrama, J. Liébana and P. Baca, "In Vitro Reduction of mutans streptococci by Means of Ozone Gas Application," Quintessence International, Vol. 39, No. 10, 2008, pp. 827831.

[10] T. G. Fragell, W. Dietz, P. Lingström, F. Steiniger and J. G. Norén, "Effect of Ozone Treatment on Different Cariogenic Microorganisms in Vitro," Swedish Dental Journal, Vol. 32, No. 3, 2008, pp. 139-147.

[11] R. S. Hems, K. Gulabivala, Y. L. Ng, D. Ready and D. A. Spratt, "An in Vitro Evaluation of the Ability of Ozone to Kill a Strain of Enterococcus faecalis," International Endodontic Journal, Vol. 38, No. 1, 2005, pp. 22-29. http://dx.doi.org/10.1111/j.1365-2591.2004.00891.x

[12] K. C. Huth, M. Quirling, S. Maier, K. Kamereck, M. Alkhayer, E. Paschos, U. Welsch, T. Miethke, K. Brand and R. Hickel, "Effectiveness of Ozone against Endodontopathogenic Microorganisms in a Root Canal Biofilm Model," International Endodontic Journal, Vol. 42, No. 1, pp. 313. http://dx.doi.org/10.1111/j.1365-2591.2008.01460.x

[13] G. M. Knight, J. M. McIntyre and P. S. Zilm, “The Inability of Streptococcus mutans and Lactobacillus acidophilus to Form a Biofilm in Vitro on Dentine Pretreated with Ozone,” Australian Dental Journal, Vol. 53, No. 4, 2008, pp. 349-353. http://dx.doi.org/10.1111/j.1834-7819.2008.00077.x

[14] I. R. Komanapalli and B. H. S. Lau, "Ozone-Induced Damage of Escherichia coli K-12,” Applied Microbiology and Biotechnology, Vol. 46, No. 5-6, 1996, pp. 610-614. http://dx.doi.org/10.1007/s002530050869

[15] P. Müller, B. Guggenheim and P. R. Schmidlin, "Efficacy of Gasiform Ozone and Photodynamic Therapy on a Multispecies Oral Biofilm in Vitro," European Journal of Oral Sciences, Vol. 115, No. 1, 2007, pp. 77-80. http://dx.doi.org/10.1111/j.1600-0722.2007.00418.x

[16] M. Nagayoshi, T. Fukuizumi, C. Kitamura, J. Yano, M. Terashita and T. Nishihara, "Efficacy of Ozone on Survival and Permeability of Oral Microorganisms," Oral Microbiology and Immunology, Vol. 19, No. 4, 2004, pp. 240-246. http://dx.doi.org/10.1111/j.1399-302X.2004.00146.x

[17] M. Oizumi, T. Suzuki, M. Uchida, J. Furuya and Y. Okamoto, "In Vitro Testing of a Denture Cleaning Method 
Using Ozone,” Journal of Medical and Dental Sciences, Vol. 45, No. 2, 1998, pp. 135-139.

[18] R. Stoll, L. Venne, A. J. Momeni, R. Mutters and V. Stachniss, "The Disinfecting Effect of Ozonized Oxygen in an Infected Root Canal: An in Vitro Study," Quintessence International, Vol. 39, No. 3, 2008, pp. 231-236.

[19] B. Thanomsub, V. Anupunpisit, S. Chanphetch, T. Watcharachaipong, R. Poonkhum and C. Srisukonth, "Effects of Ozone Treatment on Cell Growth and Ultrastructural Changes in Bacteria,” The Journal of General and Applied Microbiology, Vol. 48, No. 4, 2002, pp. 193-199. http://dx.doi.org/10.2323/jgam.48.193

[20] D. E. Cortezzo, K. Koziol Dube, B. Setlow and P. Setlow, "Treatment with Oxidizing Agents Damages the Inner Membrane of Spores of Bacillus subtilis and Sensitizes Spores to Subsequent Stress,” Journal of Applied Microbiology, Vol. 97, No. 4, 2004, pp. 838-852. http://dx.doi.org/10.1111/j.1365-2672.2004.02370.x

[21] M. Bette, R. M. Nusing, R. Mutters, Z. B. Zamora, S. Menendez and S. Schulz, "Efficiency of Tazobactam/Piperacillin in Lethal Peritonitis Is Enhanced after Preconditioning of Rats with $\mathrm{O}_{3} / \mathrm{O}_{2}$-Pneumoperitoneum," Shock, Vol. 25, No. 1, 2006, pp. 23-29. http://dx.doi.org/10.1097/01.shk.0000187983.56030.dd

[22] R. Polgnano, P. L. Vannucchi and R. Degli Innocenti, "Efficacia Antisettica Dell'Acqua Ozonizzata su Germi Isolati da Lesioni Croniche Della Cute,” Proceedings International Medical Ozone Society (IMOS) Congress, Ossigeno Ozono Terapia: Dall'Empirismo alla Metodologia Scientifica, Siena, 2000, pp. 49-50.

[23] Z. Z. Rodriguez, D. Guanche, R. G. Álvarez, F. H. Rosales, Y. Alonso and S. Schulz, "Preconditioning with Ozone/ Oxygen Mixture Induces Reversion of Some Indicators of Oxidative Stress and Prevents Organic Damage in Rats with Fecal Peritonitis,” Inflammation Research, Vol. 58, No. 7, 2009, pp. 371-375. http://dx.doi.org/10.1007/s00011-009-0001-2

[24] S. Schulz, Z. Z. Rodriguez, R. Mutters, S. Menendez and M. Bette, "Repetitive Pneumoperitoneum with Ozonized Oxigen as a Preventive in Lethal Polymicrobial Sepsis in Rats,” European Surgical Research, Vol. 35, No. 1, 2003, pp. 26-34. http://dx.doi.org/10.1159/000067032

[25] H. Steinhart, S. Schulz and R. Mutter, "Evaluation of Ozonated Oxygen in an Experimental Animal Model of Osteomyelitis as a Further Treatment Option for SkullBase Osteomyelitis," European Archives of Oto-RhinoLaryngology, Vol. 256, No. 3, 1999, pp. 153-157. http://dx.doi.org/10.1007/s004050050130

[26] Z. B. Zamora, A. B. Orlay, Y. L'opez, R. Delgado, R. González, S. Menéndez, F. Hernández and S. Schulz, "Effects of Ozone Oxidative Preconditioning on TNF- $\alpha$ Release and Antioxidant-Prooxidant Intracellular Balance in Mice during Endotoxic Shock," Mediators of Inflammation, Vol. 2005, No. 1, 2005, pp. 16-22. http://dx.doi.org/10.1155/MI.2005.16

[27] S. Burgassi, I. Zanardi, V. Travagli, E. Montomoli and V. Bocci, "How Much Ozone Bactericidal Activity Is Compromised by Plasma Components?” Journal of Applied Microbiology, Vol. 106, No. 5, 2009, pp. 1715-1721. http://dx.doi.org/10.1111/j.1365-2672.2008.04141.x

[28] S. K. Fridkin, J. C. Hageman, M. Morrison, L. T. Sanza, K. Como Sabetti, J. A. Jernigan, K. Harriman, L. H. Harrison for the Active Bacterial Core Surveillance Program of the Emerging Infection Program Network, "MethicillinResistant Staphylococcus aureus Disease in Three Communities,” New England Journal of Medicine, Vol. 352, No. 14, 2005, pp. 1436-1444. http://dx.doi.org/10.1056/NEJMoa043252

[29] R. M. Klevens, M. A. Morrison, J. Nadle, S. Petit, K. Gershman, S. Ray, L. H. Harrison and R. Lynfield, "Active Bacterial Core Surveillance (ABCs) MRSA Investigators, "Invasive Methicillin-Resistant Staphylococcus aureus Infections in the United States,” JAMA, Vol. 298, No. 15, 2007, pp. 1763-1771. http://dx.doi.org/10.1001/jama.298.15.1763

[30] G. J. Moran, A. Krishnadasan, R. J. Gorwitz, G. E. Fosheim, L. K. McDougal, R. B. Carey, D. A. Talan and Emergency ID Net Study Group, "Methicillin-Resistant S. aureus Infections among Patients in the Emergency Department," New England Journal of Medicine, Vol. 355, No. 7, 2006, pp. 666-674. http://dx.doi.org/10.1056/NEJMoa055356

[31] K. J. Popovich, R. A. Weinstein and B. Hota, “Are Community-Associated Methicillin-Resistant Staphylococcus aureus (MRSA) Strains Replacing Traditional Nosocomial MRSA Strains?” Clinical Infectious Diseases, Vol. 46, No. 6, 2008, pp. 787-794. http://dx.doi.org/10.1086/528716

[32] D. A. Robinson, A. M. Kearns, A. Holmes, D. Morrison, H. Grundmann, G. Edwards, F. G. O’Brien and F. C. Tenover, "Re-Emergence of Early Pandemic Staphylococcus aureus as a Community-Acquired Meticillin-Resistant Clone," Lancet, Vol. 365, No. 9466, 2005, pp. 12561258. http://dx.doi.org/10.1016/S0140-6736(05)74814-5

[33] J. Vallés and R. Ferrer, "Bloodstream Infections in the ICU,” Infectious Disease of North America, Vol. 23, No. 3, 2009, pp. 557-569. http://dx.doi.org/10.1016/j.idc.2009.04.005

[34] V. Bocci and L. Paulesu, "Studies on the Biological Effects of Ozone: 1. Induction of Interferon Gamma on Human Leucocytes,” Haematologica, Vol. 75, No. 6, 1990, pp. 510-515.

[35] V. Bocci, “Ozone as Bioregulator: Pharmacology and Toxicology of Ozone Therapy Today,” Journal of Biological Regulators \& Homeostatic Agents, Vol. 10, No. 2-3, 1996, pp. 31-53.

[36] V. Bocci, "Can Ozone Therapy Be Performed If the Biochemistry of the Process Cannot Be Controlled?” Archives of Medical Research, Vol. 38, No. 5, 2007, pp. 584585. http://dx.doi.org/10.1016/j.arcmed.2007.03.005

[37] N. Di Paolo, V. Bocci, G. Marosi, E. Borrelli, A. Bravi, A. Bruci, C. Aldinucci and L. Capotondo, "Extracorporeal Blood Oxygenation and Ozonization in Man. Preliminary Report," The International Journal of Artificial Organs, Vol. 23, No. 2, 2000, pp. 131-141.

[38] V. Bocci and L. Paulesu, "Studies on the Biological Effects of Ozone 5: Evaluation of Immunological Parameters and Tolerability in Normal Volunteers Receiving 
Ambulatory Autohaemotherapy,” Biotherapy, Vol. 7, No. 2, 1994, pp. 83-90. http://dx.doi.org/10.1007/BF01877731

[39] I. R. Komanapalli and B. H. S. Lau, "Inactivation of Bacteriophage k, Escherichia coli and Candida albicans by Ozone,” Applied Microbiology and Biotechnology, Vol. 49, No. 6, 1998, pp. 766-769. http://dx.doi.org/10.1007/s002530051244

[40] I. R. Komanapalli, J. B. Mudd and B. H. Lau, "Effect of Ozone on Metabolic Activities of Escherichia coli K-12," Toxicology Letters, Vol. 90, No. 1, 1997, pp. 61-66. http://dx.doi.org/10.1016/S0378-4274(96)03830-1

[41] G. Valacchi, V. Fortino and V. Bocci, "The Dual Action of Ozone on the Skin,” British Journal of Dermatology, Vol. 153, No. 6, 2005, pp. 1096-1100. http://dx.doi.org/10.1111/j.1365-2133.2005.06939.x

[42] V. Bocci, E. Luzzi, F. Corradeschi, L. Paulesu, R. Rossi, E. Cardaioli and P. Di Simplicio, "Studies on the Biological Effects of Ozone 4: Cytokine Production and Glutathione Levels in Human Erythrocytes,” Journal of Biological Regulators and Homeostatic Agents, Vol. 7, No. 4, 1993, pp. 133-138.

[43] V. Bocci, E. Luzzi, F. Corradeschi and S. Silvestri, "Studies of the Biological Effects of Ozone 6: Production of Transforming Growth Factor b1 by Human Blood after Ozone Treatment," Journal of Biological Regulators and Homeostatic Agents, Vol. 8, No. 4, 1994, pp. 108-112.

[44] W. Doroszkiewicz, I. Sikorska and S. Jankowski, "Studies on the Influence of Ozone on Complement-Mediated Killing of Bacteria," FEMS Immunology \& Medical Microbiology, Vol. 9, No. 4, 1994, pp. 281-285. http://dx.doi.org/10.1111/j.1574-695X.1994.tb00363.x

[45] L. Paulesu, E. Luzzi and V. Bocci, "Studies on the Biological Effects of Ozone 2: Induction of Tumor Necrosis Factor on Human Leucocytes,” Lymphokine and Cytokine Research, Vol. 10, No. 5, 1991, pp. 409-412.

[46] E. Riva Sanseverino, “Aspetti Immunologici Dell’Ozonoterapia,” Rivista Italiana di Omotossicologia, pp. 19-24.

[47] P. D. Thomson, G. O. Till and D. J. Smith, "Modulation of IgM Antibody Formation by Lipid Peroxidation Products from Burn Plasma,” JAMA Surgery, Vol. 126, No. 8, 1991, pp. 973-976. http://dx.doi.org/10.1001/archsurg.1991.01410320055006

[48] V. Bocci, "A Reasonable Approach for the Treatment of HIV Infection in the Early Phase with Ozone Therapy (Autohaemotherapy). How Inflammatory Cytokines May Have a Therapeutic Role,” Mediators of Inflammation,
Vol. 3, No. 5, 1994, pp. 315-321. http://dx.doi.org/10.1155/S0962935194000438

[49] M. E. Bégin, "Fatty Acids, Lipid Peroxidation and Diseases," Proceedings of the Nutrition Society, Vol. 49, No. 2, 1990, pp. 261-267. http://dx.doi.org/10.1079/PNS19900029

[50] V. Bocci, G. Valacchi, F. Corradeschi, C. Aldinucci, S. Silvestri, E. Paccagnini and R. Gerli, "Studies on the Biological Effects of Ozone 7: Generation of Reactive Oxygen Species (ROS) after Exposure of Human Blood to Ozone,” Journal of Biological Regulators and Homeostatic Agents, Vol. 12, No. 3, 1998, pp. 67-75.

[51] R. D. Buckley, J. D. Hackney, K. Clark and C. Posin, "Ozone and Human Blood," Archives of Environmental Health, Vol. 30, No. 1, 1975, pp. 40-43. http://dx.doi.org/10.1080/00039896.1975.10666631

[52] B. D. Goldstein and O. J. Balchum, "Effect of Ozone on Lipid Peroxidation in the Red Blood Cell,” Experimental Biology and Medicine, Vol. 126, No. 2, 1967, pp. 356358. http://dx.doi.org/10.3181/00379727-126-32444

[53] L. Coppola and G. Verrazzo, “Oxygen-Ozone Therapy and Haemorheological Parameters in Peripheral Chronic Arterial Disease,” Trombosi e Aterosclerosi, Vol. 3, 1992, pp. 83-89.

[54] C. Di Filippo, M. Luongo, R. Marfella, F. Ferraraccio, B. Lettieri, A. Capuano, F. Rossi and M. D’Amico, “Oxygen/Ozone Protects the Heart from Acute Myocardial Infarction through Local Increase of eNOS Activity and Endothelial Progenitor Cells Recruitment," Naunyn-Schmiedeberg's Archives of Pharmacology, Vol. 382, No. 3, 2010, pp. 287-291.

http://dx.doi.org/10.1007/s00210-010-0545-2

[55] B. A. Freeman and J. B. Mud, "Reaction of Ozone with Sulphydryls of Human Erythrocytes," Archives of Biochemistry and Biophysics, Vol. 208, No. 1, 1981, pp. 212 220. http://dx.doi.org/10.1016/0003-9861(81)90142-9

[56] A. Van Der Vliet, C. A. O’Neil, J. P. Eiserich and C. E. Cross, "Oxydative Damage to Extracellular Fluids by Ozone and Possible Protective Effects of Thiols," Archives of Biochemistry and Biophysics, Vol. 321, No. 1, 1995, pp. 4350. http://dx.doi.org/10.1006/abbi.1995.1366

[57] P. Wentworth, J. E. McDunn, A. D. Wentworth, C. Takeuchi, J. Nieva, T. Jones and C. Bautista, "Evidence for Antibody-Catalyzed Ozone Formation in Bacterial Killing and Inflammation,” Science, Vol. 298, No. 5601, 2002, pp. 2195-2199.

http://dx.doi.org/10.1126/science.1077642 